\title{
Thidiazuron Stimulates Basal Bud and Shoot Formation in Alocasia $\times$ Chantrieri André
}

\author{
R.J. Henny and W.C. Fooshee \\ Central Florida Research and Education Center-Apopka, IFAS, \\ University of Florida, Apopka, FL 32703 \\ Additional index words. growth regulators, foliage plant
}

Thidiazuron (TDZ), used to defoliate mature-green leaves in cotton before boll harvest, was first reported to possess cytokinin activity in tissue cultures of bean (Mok et al., 1982). Subsequently, it has been used to stimulate in vitro shoot formation in apple (van Niewkerk et al., 1986). However, in vivo foliar application to Abutilon theophrasti (Wymore et al., 1987) and greenhouse-grown Citrus aurantium (Pounteny and Swietlik, 1988) produced various symptoms, including leaf chlorosis, distortion and cupping of new leaves, and reduced plant growth.

No reports were found in the literature concerning use of TDZ on greenhouse-grown ornamental plants. Therefore, we tested TDZ for its potential to induce basal shoot formation in Alocasia $\times$ Chantrieri André, a self-heading nonbranching ornamental tropical foliage plant.

Sixty plants of Alocasia $\times$ Chantrieri, 16 weeks out of tissue culture, growing in 2.5cm-diameter (0.038-liter) plastic cell trays were obtained from a commercial nursery. Single plants were potted into 10 -cm-diameter (0.45-liter) plastic pots filled with Vergro Container Mix A [2 Canadian peat : 1 perlite : 1 vermiculite (by volume)], and placed in a shaded greenhouse under natural photoperiod with a maximum light intensity of $250 \mu \mathrm{mol} \cdot \mathrm{s}^{-1} \cdot \mathrm{m}^{-2}$ and in the range of 18 to $35 \mathrm{C}$. Plants were fertilized weekly with $1.0 \mathrm{~g}$ of $20 \mathrm{~N}-20 \mathrm{P}-20 \mathrm{~K}$ per liter of liquid, water-soluble fertilizer during the course of this study. Treatments were applied 1 week after potting.

Received for publication 14 Dec. 1988. Florida Agricultural Experiment Station Journal Series no. 9529. The cost of publishing this paper was defrayed in part by the payment of page charges. Under postal regulations, this paper therefore must be hereby marked advertisement solely to indicate this fact. five buds penetrated above the medium surface and produced leaves at any treatment level during the course of this experiment (Table 1). No control plants displayed any evidence of new bud development. Plant height, leaf length and width, and fresh weight of roots and shoots decreased linearly at increasing TDZ rates; shoot fresh weight also showed a significant quadratic component.

These results indicate that a single application of TDZ is effective for induction of new basal buds in Alocasia. However, the lowest TDZ rate resulted in $24 \%$ less root weight than controls and at higher rates some plants had almost no roots remaining, which indicates root loss following TDZ treatment. The plants we used were treated 1 week after potting, probably insufficient time before treatment for development of a root system better able to tolerate TDZ effects and support newly initiated buds.

\section{Literature Cited} medium at the base of a plant. There were 10 plants/treatment in a randomized complete-block design in our study, initiated 8 June 1988.

Data, recorded 12 weeks after treatment, included plant height, length, and width of the largest leaf, number of new basal shoots $>1 \mathrm{~cm}$, and shoot and root fresh weights.

Alocasia $\times$ Chantrieri treated with TDZ initiated numerous elongated buds. Total number of elongated buds increased linearly within the range of rates tested, although a significant quadratic effect was evident at the highest rate (Table 1). However, $76 \%$ to $90 \%$ of all elongated buds formed beneath the medium surface and were not visible until the soil was removed. On average, fewer than

Mok, M. C., D.W.S. Mok, D.J. Armstrong, K. Shudo, Y. Isogai, and T. Okamoto. 1982. Cytokinin activity of N-phenyl- $\mathrm{N}^{1}-1,2,3$-thiadiazol-5-ylurea (Thidiazuron). Phytochemistry 21:1509-1511.

van Niewkerk, J. P., R.H. Zimmerman, and I. Fordham. 1986. Thidiazuron stimulation of apple shoot proliferation in vitro. HortScience 21:516-518.

Pountney, C. and D. Swietlik. 1988. Growth and physiological responses of grapefruit trees and sour orange seedlings to thidiazuron. HortScicnce 23:119. (Abstr.)

Wymore, L. A., A.K. Watson, and A.R. Gotlieb. 1987. Interaction between Collectotrichum coccodes and thidiazuron for control of velvetleaf (Abutilon theophrasti). Weed Sci. 35:377-383,

Table 1. Effect of thidiazuron (TDZ) on production of new elongated buds, basal shoots, and overall plant growth of Alocasia $\times$ Chantrieri.

\begin{tabular}{|c|c|c|c|c|c|c|c|c|}
\hline \multirow{2}{*}{$\begin{array}{c}\mathrm{TDZ} \\
\text { concn }^{2} \\
\left(\mathrm{mg} \cdot \text { liter }^{-1}\right)\end{array}$} & \multirow{2}{*}{$\begin{array}{c}\text { Total } \\
\text { elongated } \\
\text { buds }^{y} \\
\text { (no.) }\end{array}$} & \multirow{2}{*}{$\begin{array}{c}\text { Visible } \\
\text { basal shoots } \\
\text { (no.) }\end{array}$} & \multirow{2}{*}{$\begin{array}{c}\text { Plant } \\
\text { ht } \\
(\mathrm{cm})\end{array}$} & \multirow{2}{*}{$\begin{array}{c}\text { Leaf } \\
\text { length } \\
(\mathrm{cm})\end{array}$} & \multirow{2}{*}{$\begin{array}{l}\text { Leaf } \\
\text { width } \\
(\mathrm{cm})\end{array}$} & \multicolumn{2}{|c|}{$\begin{array}{l}\text { Fresh } \\
\text { wt (g) }\end{array}$} & \multirow{2}{*}{$\begin{array}{l}\text { Shoot : } \\
\text { root } \\
\text { ratio }\end{array}$} \\
\hline & & & & & & Shoot & Root & \\
\hline $0^{y}$ & 0.0 & 0.0 & 22.7 & 20.4 & 8.9 & 40.1 & 13.0 & 3.2 \\
\hline 1 & 13.9 & 1.8 & 23.8 & 20.2 & 9.2 & 50.2 & 9.9 & 6.9 \\
\hline 5 & 38.3 & 4.6 & 18.1 & 14.3 & 6.3 & 40.8 & 3.1 & 22 \\
\hline 10 & 33.6 & 3.5 & 16.9 & 10.8 & 5.6 & 23.8 & 0.9 & 32 \\
\hline \multicolumn{9}{|l|}{ Significance ${ }^{x}$} \\
\hline Linear & $* *$ & $* *$ & ** & $* *$ & $* *$ & $* *$ & $* *$ & $* *$ \\
\hline Quadratic & $*$ & $*$ & NS & NS & NS & $* *$ & NS & NS \\
\hline Residual & NS & NS & $*$ & NS & $*$ & NS & NS & NS \\
\hline
\end{tabular}

${ }^{2}$ Ten plants per treatment; each plant received $10 \mathrm{ml}$ of treatment solution applied as a drench at its base on 8 June 1988 .

${ }^{y}$ Means in this column are a combination of elongated buds and visible basal shoots

${ }^{\mathrm{x}}$ Regression analyses were performed on tests with significant differences between treatments as determined by an $\mathrm{F}$ test. 